\title{
Growth hormone-induced blood pressure decrease is associated with increased mRNA levels of the vascular smooth muscle $K_{\text {ATP }}$ channel
}

\author{
Åsa Tivesten ${ }^{1}$, Anna Barlind ${ }^{1}$, Kenneth Caidahl ${ }^{\mathbf{2}}$, \\ Natalia Klintland ${ }^{2}$, Antonio Cittadini ${ }^{3}$, Claes Ohlsson ${ }^{1}$ and \\ Jörgen Isgaard ${ }^{\mathbf{1}}$ \\ ${ }^{1}$ Research Center for Endocrinology and Metabolism, Department of Internal Medicine, Sahlgrenska University Hospital, S-413 45 Göteborg, Sweden \\ ${ }^{2}$ Department of Clinical Physiology, Sahlgrenska University Hospital, S-413 45 Göteborg, Sweden \\ ${ }^{3}$ Department of Internal Medicine and Cardiovascular Sciences, University Federico II, 80131 Naples, Italy \\ (Requests for offprints should be addressed to ^̊ Tivesten; Email: asa.tivesten@medic.gu.se)
}

\begin{abstract}
Growth hormone $(\mathrm{GH})$ deficiency is associated with abnormal vascular reactivity and development of atherosclerosis. $\mathrm{GH}$ treatment in $\mathrm{GH}$ deficient states restores systemic vascular resistance, arterial compliance, endothelium-dependent and endothelium-independent vasodilation, and may reverse markers of early atherosclerosis. However, very little is known about the molecular mechanisms underlying these effects. In the present study, male Sprague Dawley rats were hypophysectomized and treated for two weeks with GH (recombinant human $\mathrm{GH}, 2 \mathrm{mg} / \mathrm{kg} /$ day) or saline as s.c. injections twice daily. GH decreased aortic systolic blood pressure compared with saline-treated animals, while the diastolic blood pressure was not significantly changed. GH treatment increased cardiac output as determined by Dopplerechocardiography and the calculated systemic vascular resistance was markedly reduced. In order to identify
\end{abstract}

GH-regulated genes of importance for vascular function, aortic mRNA levels were analyzed by the microarray technique and correlated to the systolic blood pressure levels. Using this approach, we identified $18 \mathrm{GH}-$ regulated genes with possible impact on vascular tone and atherogenesis. In particular, mRNA levels of the inwardly rectifying potassium channel Kir6.1 and the sulfonylurea receptor $2 \mathrm{~B}$, which together form the vascular smooth muscle ATP-sensitive potassium channel, were both upregulated by GH treatment and highly correlated to systolic blood pressure. Our findings establish a major role for $\mathrm{GH}$ in the regulation of vascular physiology and gene expression. Increased expression of the ATP-sensitive potassium channel, recently shown to be crucial in the regulation of vascular tone, constitutes a possible mechanism by which GH governs vascular tone.

Journal of Endocrinology (2004) 183, 195-202

\section{Introduction}

In addition to its growth-promoting and metabolic effects, growth hormone $(\mathrm{GH})$ has an important impact on cardiovascular physiology. Besides affecting cardiac structure and contractility (Fazio et al. 1997, Longobardi et al. 2000, Barreto-Filho et al. 2002), both experimental and clinical GH deficiency has been associated with increased systemic vascular resistance (Fazio et al. 1997, Longobardi et al. 2000) and abnormal vascular reactivity (Rossoni et al. 1999, Evans et al. 2000, Capaldo et al. 2001). Accordingly, an increased prevalence of hypertension (Barreto-Filho et al. 2002) and atherosclerotic disease (Pfeifer et al. 1999) has been reported among patients with GH deficiency, and hypopituitary patients show increased cardiovascular morbidity and mortality (Rosen \& Bengtsson 1990). GH treatment in $\mathrm{GH}$ deficient states has been shown to normalize systemic vascular resistance (Boger et al. 1996, Longobardi et al. 2000), arterial stiffness (Smith et al. 2002), endothelial and/or endothelium-independent vasodilation (Rossoni et al. 1999, Evans et al. 2000, Capaldo et al. 2001), and may reverse markers of early atherosclerosis (Pfeifer et al. 1999).

Despite the data supporting a physiological role for $\mathrm{GH}$ in the vascular system, very little is known about the molecular mechanisms underlying its effects, and it is currently unknown how GH treatment affects vascular global gene expression. We therefore assessed the effects of $\mathrm{GH}$ on aortic gene expression in GH-deficient hypophysectomized rats. In order to identify genes of importance 
for vascular physiology, aortic mRNA levels were correlated to systolic blood pressure levels. Using this approach, we identified GH-regulated genes with potential impact on vascular tone and atherogenesis.

\section{Materials and Methods}

\section{Animals}

Male Sprague Dawley rats (170-190 g), were hypophysectomized ( $\mathrm{Hx}$ ) by the vendor (Iffa Credo, L'Arbresle Cedex, France). One week after hypophysectomy, replacement therapy with hydrocortisone $(400 \mu \mathrm{g} / \mathrm{kg} /$ day; Solu-Cortef, Pharmacia Sweden AB, Stockholm, Sweden) and levothyroxine $(20 \mu \mathrm{g} / \mathrm{kg} /$ day; Nycomed, Lidingö, Sweden) as daily s.c. injections was started in our laboratory. The animals were housed in a temperature- and humidity-controlled room with a 0600-1800 h light cycle and standard rat pellets and tap water were available ad libitum. Anesthesia was performed with isoflurane (Baxter Medical AB, Kista, Sweden) and all procedures were approved by the ethics committee at Göteborg University and conformed to the Universities Federation for Animal Welfare Handbook on the Care and Management of Laboratory Animals.

\section{Study protocol}

Two weeks after hypophysectomy, an echocardiographic examination was performed ('baseline'). The rats were then treated for two weeks with GH (recombinant human $\mathrm{GH}, 2 \mathrm{mg} / \mathrm{kg} /$ day, Genotropin, Pharmacia Sweden AB, $n=11)$ or saline $(0 \cdot 9 \% \mathrm{NaCl}, n=11)$. The treatments were given as s.c. injections twice daily. After the treatment period, a second echocardiographic examination was performed ('2 weeks') and invasive blood pressure was recorded. The last injections of $\mathrm{GH} /$ saline were given 10 and $3 \mathrm{~h}$ before killing the rats. Blood was collected from the arterial catheter and the animals were killed by excision of the heart. The thoracic aorta was dissected free from blood and surrounding tissue, rinsed and frozen.

\section{Echocardiography}

Cardiac ultrasound studies were performed using a commercially available ultrasonograph (ATL, HDI 5000 SonoCT, Philips Ultrasound, Bothell, Seattle, WA, USA) equipped with a $15 \mathrm{MHz}$ linear array transducer. Pulsedwave Doppler signals $(5 \mathrm{MHz})$ and velocity time integrals were obtained from the pulmonary artery and the pulmonary artery diameter was measured. Stroke volume was calculated as the product of the mean velocity time integral and the corresponding pulmonary artery area (Baily et al. 1993). Multiplying stroke volume by heart rate yielded cardiac output. Cardiac index was calculated as cardiac output divided by body weight and systemic vascular resistance was calculated as mean arterial pressure (Christensen et al. 1990)/cardiac index.

\section{Blood pressure measurements}

During anesthesia, a PE50 catheter was inserted into the aortic arch via the left carotid artery. Blood pressure variables were measured using a pressure transducer (P23DC, Gulton Statham Transducers Inc, Costa Mesa, CA, USA) connected to a Grass model 7D polygraph (Quincey, MA, USA). Blood pressure values were calculated as means of 12 samples taken during $60 \mathrm{~s}$.

\section{Microarray analysis and bioinformatics}

Total RNA was extracted from the aorta of 5-6 animals per treatment group (saline and GH respectively) with Trizol Reagent (Invitrogen AB, Carlsbad, CA, USA) according to the manufacturer's instructions. The RNA from the individual animals was reverse transcribed into cDNA, labeled and analyzed by DNA microarray (Rat genome U34A array; Affymetrix, Santa Clara, CA, USA). The array represents approximately 7000 known rat genes and approximately 1000 uncharacterized expressed sequence tag (EST) clusters. Preparation of labeled cRNA and hybridization were carried out according to the Affymetrix Gene Chip Expression Analysis manual (for more information, see www.affymetrix.com). Scanned output files were analyzed using Affymetrix Microarray Suite Version $5 \cdot 0$ software. To allow comparison of gene expression, the gene chips were globally scaled to an average intensity of 100 . A significant detection $P$-value in all of the saline- and GH-treated individuals was demanded for each probe set. The probe sets classified as present using this procedure $(n=2363)$ were included in further analyses.

Using the signal intensity of the probe set of each individual, a $t$-test was performed for the comparison of saline $(n=5)$ versus GH $(n=6)$. Probe sets showing a $P$-value of $<0.01$ and a regulation of $\geq 1 \cdot 5$-fold (corresponding to $50 \%$ up-regulation or $33 \%$ down-regulation) were then called GH regulated. To identify GH-regulated probe sets of potential importance for vascular function, correlation coefficients (Pearson's $r$ ) were calculated for the association between the signal intensity of each GH-regulated probe set and systolic blood pressure. An arbitrary limit of $r$ of $\geq 0.75$ or $\leq-0.75$ was chosen. All probe sets with a correlation coefficient compared with systolic blood pressure of $\geq 0.75$ or $\leq-0.75$ were significantly correlated $(P<0 \cdot 05)$ to systolic blood pressure according to the non-parametric Spearman rank order correlation test.

\section{Real-time PCR}

The PCR analysis was performed using the ABI Prism 7000 Sequence Detection System (PE Applied 
Biosystems, Stockholm, Sweden) using a FAM-labeled probe specific for the Kir6.1 transcript (PE Applied Biosystems). Forward primer, reverse primer and probe corresponded to the base coordinates 752-770, 820-801 and 773-798 of the rat Kir6.1 mRNA (accession number D42145). Pre-designed primers and a VIC-labeled probe for $18 \mathrm{~S}$ rRNA were used as internal standard. The cDNA was amplified $\left(50{ }^{\circ} \mathrm{C} / 2 \mathrm{~min}\right.$ and $95^{\circ} \mathrm{C} / 10 \mathrm{~min}$, followed by 40 cycles at $95^{\circ} \mathrm{C} / 15 \mathrm{~s}$ and $60{ }^{\circ} \mathrm{C} / 1 \mathrm{~min}$ ) and the mRNA amount of each gene was calculated using the Standard Curve Method (User Bulletin \#2, PE Applied Biosystems) and adjusted for the expression of $18 \mathrm{~S} \mathrm{rRNA}$.

\section{Analyses of serum insulin-like growth factor-I (IGF-I) and plasma nitrate}

Serum was assayed for IGF-I by an IGF binding proteinblocked radioimmunoassay using a commercial kit (Mediagnost, Reutlingen, Germany) and plasma nitrate levels were determined by gas chromatography and mass spectrometry as previously described (Ringqvist et al. 2000).

\section{Statistical analysis}

All values are expressed as the mean \pm S.E.M. Student's $t$-test and correlation coefficients (Pearson's $r$ ) were used for the selection of microarray data (as described above). For all other variables, statistical significance was assessed by the Mann-Whitney $U$-test and the Spearman rank order correlation test. For variables assessed before and after treatment (i.e. body weight and echocardiographic variables), statistical analysis was performed on the delta values. A value of $P<0 \cdot 05$ was considered statistically significant.

\section{Results}

\section{Effects of GH on body weight gain and serum IGF-I}

As expected, $\mathrm{GH}$ treatment of $\mathrm{Hx}$ rats for 2 weeks markedly increased body weight gain $(78.8 \pm 1 \cdot 6$ versus $3.5 \pm 1.7 \mathrm{~g}$ in the saline group, $P<0.0001)$. Likewise, serum IGF-I levels, measured at the end of the treatment period, were increased by GH $(792 \pm 32$ versus $29 \pm 2 \mathrm{ng} / \mathrm{ml}$ in saline-treated rats, $P<0 \cdot 0001)$.

\section{Effects of GH on blood pressure, cardiac output and systemic vascular resistance}

To assess the effect of $\mathrm{GH}$ on blood pressure, invasive blood pressure measurements were performed after 2 weeks of treatment. GH decreased systolic blood pressure, while the diastolic blood pressure was not significantly affected (Fig. 1A,B). Doppler-echocardiographic measurements of cardiac output were performed before and after treatment (Table 1). GH treatment did not cause any
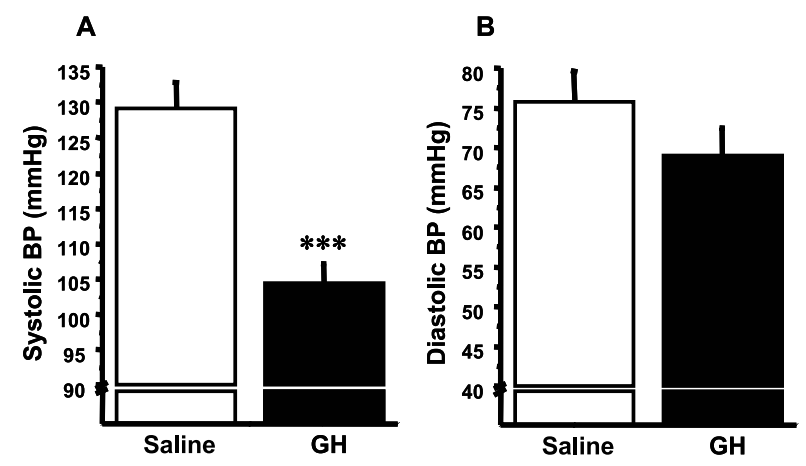

Figure 1 (A) Systolic and (B) diastolic blood pressure measured via catheterization of the carotid artery after 2 weeks of treatment of $\mathrm{Hx}$ rats with saline or $\mathrm{GH}$. BP, blood pressure. ${ }^{* * *} P<0 \cdot 001$ compared with saline, based on the Mann-Whitney $U$-test.

detectable changes in heart rate, but cardiac output was increased by treatment with GH and the calculated body weight-adjusted systemic vascular resistance was markedly reduced by GH (Table 1).

\section{Effects of $\mathrm{GH}$ on aortic gene expression}

DNA microarray analyses were performed on RNA samples from the aorta of individual saline- or GH-treated Hx rats ( $n=5$ and 6 per treatment group respectively) to investigate if treatment with $\mathrm{GH}$ altered the vascular global gene expression pattern. Using the criteria of an up- or down-regulation of at least $1 \cdot 5$-fold and a $P$-value of $<0 \cdot 01,94$ probe sets were identified as $\mathrm{GH}$ regulated. These 94 probe sets represented 67 known genes, 15 duplicates and 12 ESTs (see supplementary table in the online version of Journal of Endocrinology at http:// joe.endocrinology-journals.org/content/vol183/issue1/).

Correlation between gene expression and systolic blood pressure

In order to identify GH-regulated genes of relevance for vascular function, aortic mRNA levels were correlated to systolic blood pressure. For each of the $94 \mathrm{GH}$-regulated probe sets, a correlation coefficient was calculated between the signal intensity in the microarray analysis and the aortic systolic blood pressure level. Twenty-nine probe sets, representing 18 known genes (Table 2) with 5 duplicates, 5 unassigned ESTs and 1 non-specific sequence (see supplementary table in the online version of Journal of Endocrinology at http://joe.endocrinology-journals.org/ content/vol183/issue1/), showed a correlation coefficient $(r)$ of $\geq 0.75$ or $\leq-0.75$. The 18 known genes could be sorted into different functional categories, i.e. vascular tone, anti-oxidation, cell adhesion/inflammation, fibrinolysis, nerve growth factor (NGF)-associated genes, cytoskeleton/extracellular matrix, amino acid transport and intracellular signaling/processing (Table 2).

Interestingly, the inwardly rectifying potassium channel Kir6.1, which has been shown to be critical for the 
Table 1 Effect of GH on heart rate, cardiac output and systemic vascular resistance. Values are means \pm S.E.M.

\begin{tabular}{|c|c|c|c|}
\hline & Saline & GH & $P$-value \\
\hline $\begin{array}{l}\text { Heat rate (beats/min) } \\
\text { Baseline } \\
2 \text { weeks }\end{array}$ & $\begin{array}{l}328 \pm 8 \\
317 \pm 12\end{array}$ & $\begin{array}{l}323 \pm 6 \\
331 \pm 18\end{array}$ & $>0 \cdot 20$ \\
\hline $\begin{array}{l}\text { Cardiac output }(\mathrm{ml} / \mathrm{min}) \\
\text { Baseline } \\
2 \text { weeks }\end{array}$ & $\begin{array}{r}83 \pm 5 \\
111 \pm 8\end{array}$ & $\begin{array}{c}93 \pm 5 \\
209 \pm 12\end{array}$ & $0 \cdot 0001$ \\
\hline $\begin{array}{l}\text { Cardiac index }(\mathrm{ml} / \mathrm{min} / 100 \mathrm{~g}) \\
\text { Baseline } \\
2 \text { weeks }\end{array}$ & $\begin{array}{l}57 \pm 4 \\
75 \pm 5\end{array}$ & $\begin{array}{l}64 \pm 3 \\
93 \pm 5\end{array}$ & $0 \cdot 11$ \\
\hline $\begin{array}{l}\text { Systemic vascular resistance }(\mathrm{mmHg} \cdot \mathrm{kg} / \mathrm{l} / \mathrm{min}) \\
2 \text { weeks }\end{array}$ & $141 \pm 13$ & $94 \pm 5$ & $0 \cdot 0012$ \\
\hline
\end{tabular}

On data available before and after treatment, statistical comparisons (GH vs saline) were performed on the delta values. $P$-values are based on the Mann-Whitney U-test.

regulation of vascular tone (Miki et al. 2002), was upregulated by $103 \%$ by $\mathrm{GH}$ treatment and showed a strong negative correlation to systolic blood pressure (Fig. 2A, B). Kir6.1 mRNA expression was also strongly correlated to systemic vascular resistance $(r=0 \cdot 75)$. Together with the sulfonylurea receptor 2B (SUR2B), Kir6.1 forms the vascular smooth muscle ATP-sensitive potassium $\left(\mathrm{K}_{\mathrm{ATP}}\right)$ channel (Miki et al. 2002). Having established that GH treatment increases vascular Kir6.1 mRNA levels, we therefore looked specifically for the SUR2B among the

Table 2 GH-regulated genes highly correlated to systolic blood pressure. Genes regulated by GH $(P$-value in a t-test vs saline of $<0.01$ and an up- or down-regulation of $\geq 1 \cdot 5$-fold) with a correlation coefficient vs systolic blood pressure of $\geq 0.75$ or $\leq-0.75$

\begin{tabular}{|c|c|c|c|c|}
\hline \multirow[b]{2}{*}{$\begin{array}{l}\text { Accession no. } \\
\text { Vascular tone }\end{array}$} & & Change (\%) & $\boldsymbol{P}$ & Corr $(r)$ \\
\hline & \multicolumn{4}{|l|}{ Title } \\
\hline D42145 & Potassium inwardly-rectifying channel, Kir6.1 & +103 & $\star * \star * *$ & $-0 \cdot 82$ \\
\hline \multicolumn{5}{|l|}{ Anti-oxidation } \\
\hline K01932 & Glutathione-S-transferase, alpha type & +76 & $* * * *$ & -0.76 \\
\hline \multicolumn{5}{|c|}{ Cell adhesion/inflammation } \\
\hline X63594 & IkappaB-alpha & -54 & $* * * * *$ & $0 \cdot 76$ \\
\hline X61381 & Interferon-inducible protein 10 & +52 & $* * *$ & $-0 \cdot 78$ \\
\hline \multicolumn{5}{|l|}{ Fibrinolysis } \\
\hline M23697 & Tissue plasminogen activator & -52 & $* * * * *$ & $0 \cdot 75$ \\
\hline \multicolumn{5}{|c|}{ Nerve growth factor-associated } \\
\hline E03082 & Neurotropin-3/nerve growth factor-2 & -50 & ** & $0 \cdot 94$ \\
\hline M60921 & NGF-inducible anti-proliferative secreted protein & -59 & $* * *$ & $0 \cdot 92$ \\
\hline AA799575 & Peptidylglycine alpha-amidating monooxygenase & -34 & $* *$ & $0 \cdot 91$ \\
\hline M18416 & Nerve growth factor-induced gene- $\mathrm{A}$ & -58 & ** & $0 \cdot 79$ \\
\hline A03913 & Glia-derived neurite-promoting factor & -47 & $* * *$ & $0 \cdot 76$ \\
\hline \multicolumn{5}{|c|}{ Cytoskeleton/extracellular matrix } \\
\hline X65036 & Integrin alpha-7 & -51 & $* * *$ & $0 \cdot 82$ \\
\hline S77494 & Lysyl oxidase & -40 & $* * *$ & $0 \cdot 77$ \\
\hline AA892897 & Procollagen-lysine & -46 & $* * * *$ & $0 \cdot 78$ \\
\hline U24489 & Tenascin-X & +61 & $* *$ & $-0 \cdot 77$ \\
\hline X80130 & Alpha-actin cardiac protein & +97 & $* * *$ & $-0 \cdot 81$ \\
\hline \multicolumn{5}{|c|}{ Amino acid transport } \\
\hline M96601 & Taurine transporter & -40 & $* * *$ & $0 \cdot 75$ \\
\hline \multicolumn{5}{|c|}{ Intracellular signaling/processing } \\
\hline S81478 & CL100 protein-tyrosine phosphatase & -57 & $* * *$ & $0 \cdot 80$ \\
\hline D21132 & Phosphotidylinositol transfer protein, beta & -35 & $* * *$ & $0 \cdot 80$ \\
\hline
\end{tabular}


A

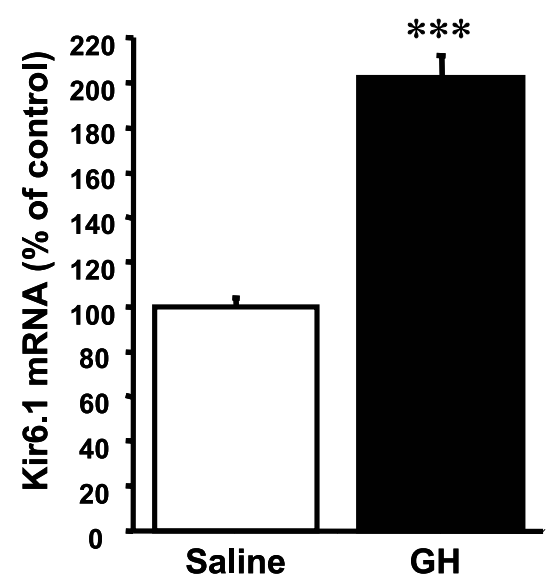

C

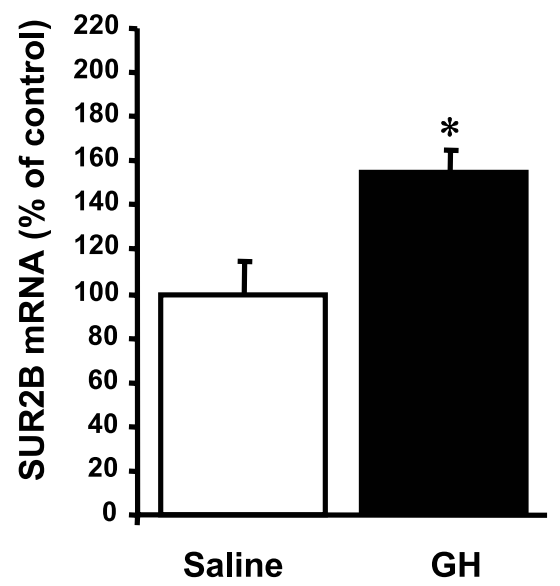

B

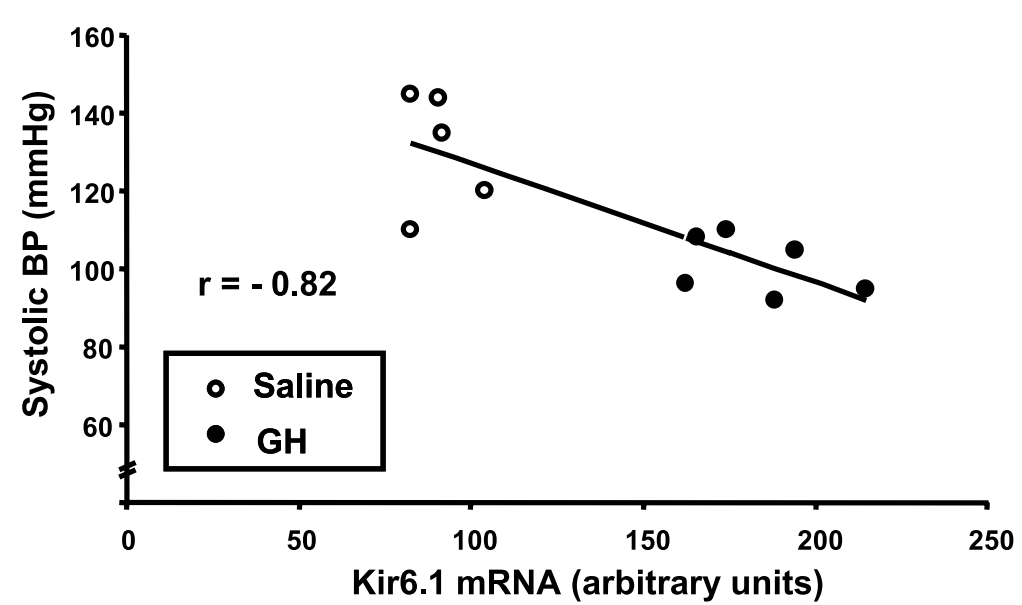

D

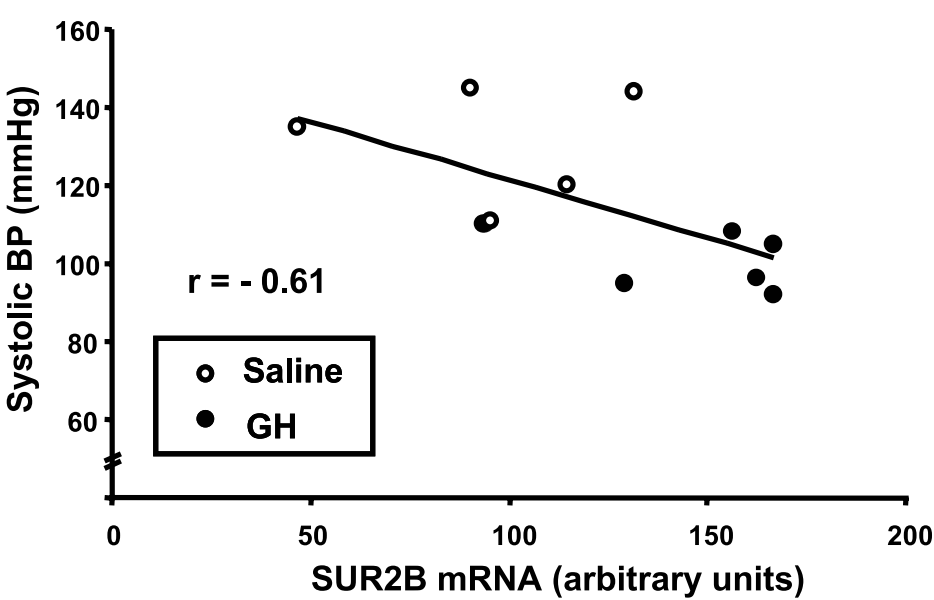

Figure 2 Quantification of Kir6 1 mRNA by microarray (A; $n=5-6$ per group) and correlation between Kir6 1 mRNA and systolic blood pressure ( $\mathrm{B} ; \mathrm{P}=0.0095$ according to the Spearman rank order correlation test) in saline- and $\mathrm{GH}$-treated Hx rats. Quantification of SUR2B mRNA by microarray (C; $n=5-6$ per group) and correlation between SUR2B mRNA and systolic blood pressure (D; $P=0 \cdot 028)$ in saline- and $\mathrm{GH}$-treated $\mathrm{Hx}$ rats. ${ }^{*} P<0 \cdot 05,{ }^{* * *} P<0 \cdot 001$ compared with saline, based on a $t$-test.

microarray data. Indeed, although not identified initially using our strict criteria of regulation, there was a significant increase in the mRNA levels of the SUR2B (accession number AF019628/AF087839), and the mRNA levels showed a negative correlation to systolic blood pressure (Fig. 2C, D). Furthermore, glutathione S-transferase was up-regulated and a large group of NGF-associated genes was down-regulated by $\mathrm{GH}$.

As mRNA levels of I-kappaB, the inhibitor of nuclear factor (NF)-kappaB, were decreased by GH treatment, we looked specifically for a possible regulation of NF-kappaB. Moreover, we searched for a possible regulation of vascular cell adhesion molecule-1 (VCAM-1), an important adhe- sion molecule involved in atherogenesis (Cybulsky et al. 2001) and known to be regulated by the NF-kappaB system (Kunsch \& Medford 1999). The NF-kappaB mRNA was classified as present but was not regulated by GH (data not shown). However, GH significantly decreased the mRNA levels of VCAM-1 ( $-32 \%, P=0 \cdot 0007$, accession number X63722), and VCAM-1 mRNA was strongly correlated to systolic blood pressure $(r=0 \cdot 75, P=0 \cdot 045)$.

\section{Real-time PCR confirmation of Kir6.1 regulation}

In order to confirm the results from the microarray analyses, we performed a real-time PCR assay to quantify 
A

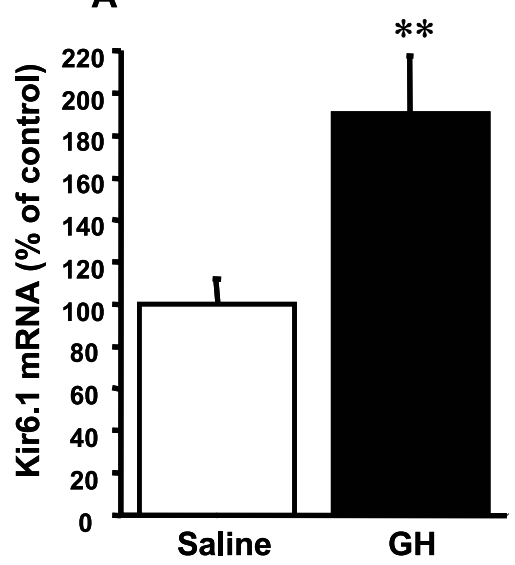

B

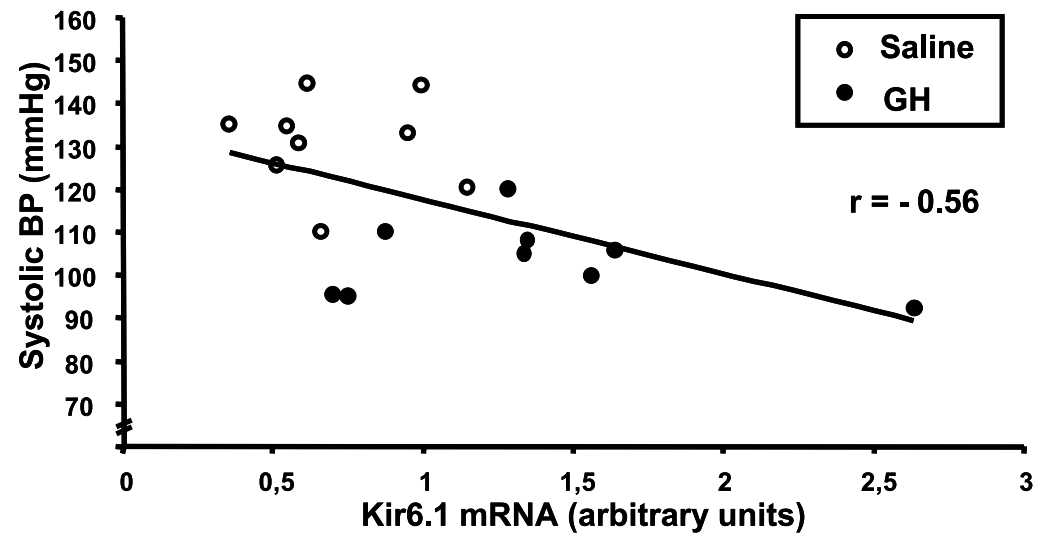

Figure 3 Quantification of Kir6·1 mRNA by real-time PCR (A; $n=9$ per group) and correlation between Kir6 1 mRNA levels quantified by real-time PCR and systolic blood pressure (B; $P=0.016$ according to the Spearman rank order correlation test). ${ }^{* *} P<0 \cdot 01$ compared with saline, based on the Mann-Whitney $U$-test.

Kir6.1 mRNA levels. Quantification by real-time PCR (Fig. 3A) gave comparable results to the microarray analysis of Kir6.1 mRNA levels (Fig. 2A). In addition, the negative correlation seen for Kir6.1 mRNA quantified by microarray was confirmed when the real-time PCR data were correlated to systolic blood pressure (Fig. 3B).

\section{Effects of GH on plasma nitrate levels}

To evaluate if the GH-induced reduction of vascular resistance was associated with increased formation of nitric oxide, we studied the effect on plasma nitrate levels as a marker of systemic nitric oxide production (Ringqvist et al. 2000). However, there was no difference in plasma nitrate levels between $\mathrm{GH}$ - and saline-treated rats $(23 \cdot 0 \pm 1 \cdot 0$ and $23 \cdot 4 \pm 1 \cdot 0 \mu \mathrm{mol} / 1 \mathrm{respectively})$.

\section{Discussion}

In this report, we have explored the molecular mechanisms underlying the actions of $\mathrm{GH}$ on vascular function by examining aortic mRNA levels assessed by microarray. We have demonstrated that GH regulates the mRNA levels of a large number of genes in vascular tissue, paralleling a decrease in systolic blood pressure. Our most important finding is that $\mathrm{GH}$ regulates the mRNA levels of the two subunits of the $\mathrm{K}_{\mathrm{ATP}}$ channel, known to be critical in the regulation of vascular tone (Miki et al. 2002). Moreover, GH regulates the mRNA levels of genes that may be implicated in atherogenesis.

\section{Decreased vascular tone by $\mathrm{GH}-$ a role for the} Kir6 $1 /$ SUR2B channel

Several studies have consistently demonstrated decreased systemic vascular resistance in association with increased cardiac output by GH treatment of normal or GHdeficient rats (Cittadini et al. 1996, Longobardi et al. 2000, Tivesten et al. 2001). These effects remain after adjustment for body size. Blood pressure levels may be decreased, as in the present study, or unchanged (Longobardi et al. 2000, Tivesten et al. 2001, Smith et al. 2002). Given the permissive role of the heart in adjusting cardiac output to systemic vascular resistance in order to maintain normal blood pressure levels, it is reasonable to suggest that a large part of the hemodynamic effects of $\mathrm{GH}$ is mediated through an effect on vascular tone. The effect on vascular tone may be a direct effect of $\mathrm{GH}$, or mediated by local or circulating IGF-I (Tivesten et al. 2002).

In the present study, GH administration up-regulated aortic mRNA levels of the inwardly rectifying potassium channel Kir6.1, and the mRNA levels of Kir6.1 were strongly correlated to systolic blood pressure. Kir6 1 forms the vascular smooth muscle $\mathrm{K}_{\text {ATP }}$ channel together with the SUR2B (Fujita \& Kurachi 2000). Looking specifically for SUR2B in our array data, we found that $\mathrm{GH}$ also up-regulated the SUR2B component of the $\mathrm{K}_{\mathrm{ATP}}$ channel. A recent study has shown that the phenotype of Kir6-1-null mice is characterized by coronary vasoconstriction, suggesting that the Kir6 1 -containing $\mathrm{K}_{\text {ATP }}$ channel is critical for the regulation of vascular tone (Miki et al. 2002). The vascular $\mathrm{K}_{\mathrm{ATP}}$ channel is also the target for the anti-hypertensive potassium channel opening drugs, which potently reduce systemic blood pressure levels (Fujita \& Kurachi 2000). We therefore propose that an up-regulation of the $\mathrm{K}_{\mathrm{ATP}}$ channel expression may result in a decreased vascular tone and thus constitutes a possible mechanism by which $\mathrm{GH}$ governs vascular resistance.

Stimulation of beta-adrenoreceptors leads to vascular dilation through a mechanism involving activation of the $\mathrm{K}_{\mathrm{ATP}}$ channel (Fujii et al. 1999). GH has been shown to 
improve the aortic relaxation of aged rats in response to beta-adrenergic stimulation (Castillo et al. 2003). In view of our present findings, this result may be attributable to a $\mathrm{GH}$-induced increase in vascular $\mathrm{K}_{\mathrm{ATP}}$ channel expression.

GH treatment of GH deficient patients increased urinary levels of nitrate, suggesting an increased vascular production of nitric oxide (Boger et al. 1996). In the present study, GH did not increase plasma nitrate levels, arguing against a major role of increased nitric oxide production for the observed blood pressure effect. Several studies have shown that GH, or IGF-I, may cause vasorelaxation through endothelium-independent mechanisms (Hasdai et al. 1998, Capaldo et al. 2001). In line with these data, our finding of increased vascular Kir6.1 mRNA levels by GH supports the notion of an endotheliumindependent vasodilatory mechanism activated by $\mathrm{GH}$.

We chose to correlate aortic gene expression to aortic systolic blood pressure, which is composed of a pulsatile and a steady component with different determinants (Safar et al. 2003), e.g. compliance of large arteries and systemic vascular resistance. For practical reasons, it was not possible to dissect these components within this study and this will be a challenge for future studies.

In the present study, we used human GH which may activate both the GH receptor and the prolactin receptor in the rat (Goffin et al. 1996). Therefore, an effect of prolactin receptor activation on gene expression cannot be excluded. However, prolactin has been reported to increase, rather than decrease, blood pressure in rats (Mills \& Woods 1985) and thus the blood pressure-lowering effect of $\mathrm{GH}$ in the present study is likely to be an effect of GH receptor stimulation.

\section{Regulation of genes implicated in atherogenesis}

It is well known that inflammatory processes are involved in atherogenesis and a large body of evidence has implicated enhanced oxidative stress in the atherogenic process (Kunsch \& Medford 1999). Oxidative stress, measured as lipid-derived free radicals, was elevated in a cohort of $\mathrm{GH}$ deficient patients but fell significantly during GH replacement therapy, paralleled by improvement of endothelial function (Evans et al. 2000). In the present study, we found that the alpha type of glutathione S-transferase was up-regulated by GH. The glutathione S-transferases have been proposed as an important defence in the vascular media, protecting blood vessels against oxidative stress $(\mathrm{He}$ et al. 1998). Thus, increased expression of glutathione S-transferase by GH may promote anti-oxidation and thereby neutralize atherogenic stimuli.

VCAM-1 is a vascular inflammatory gene considered to have a key role in the early phases of atherosclerosis by monocyte recruitment to atherosclerotic lesions (Cybulsky et al. 2001). In the present study, GH down-regulated VCAM-1, which should create an anti-atherogenic vascular milieu. The regulation of VCAM-1 expression occurs through a reduction/oxidation-sensitive mechanism involving the transcription factor NF-kappaB (Kunsch \& Medford 1999). We could not detect any change in NF-kappaB mRNA levels, while GH down-regulated its inhibitor, I-kappaB alpha. Given the complexity of the NF-kappaB/I-kappaB system (Ting \& Endy 2002), further studies should address the interactions between $\mathrm{GH}$ and NF-kappaB/I-kappaB in the vascular wall.

\section{NGF-associated genes}

The neurotropins are a family of related growth factors, including neurotropin-3 and NGF. Neurotropin-3, also called NGF-2, and several genes known to be induced by NGF, such as NGF-inducible anti-proliferative secreted protein, peptidylglycine alpha-hydroxylating monooxygenase and NGF-induced gene A, were down-regulated by $\mathrm{GH}$ and showed a positive correlation to systolic blood pressure levels.

Messenger RNA of neurotropin-3 is co-expressed with NGF within the cardiovascular system (Scarisbrick et al. 1993). While data on vascular effects of neurotropin-3 are sparse, NGF has been shown to decrease vascular tone and modulate sympathetic innervation and vascular smooth muscle growth (Zettler et al. 1991, Emanueli et al. 2002). The neurotropins have also been shown to be regulated in the response to vascular injury and stretch of vascular smooth muscle cells (Clemow et al. 2000). Taken together, these findings suggest that the neurotropins play an important role in vascular biology. In the current setting, we suggest that the decrease in neurotropin mRNA levels may be secondary to the unloading of the arterial wall during GH treatment.

\section{Summary}

Despite the extensive data supporting a physiological role for $\mathrm{GH}$ in the vascular system and that attention recently has been focused on $\mathrm{GH}$ as a new therapeutic alternative in the treatment of heart failure (Isgaard et al. 1998), little is known about the molecular mechanisms underlying the vascular effects of GH. In the present study we have identified a number of vascular genes of potential importance for the action of GH. In particular, we suggest that the vascular smooth muscle $\mathrm{K}_{\mathrm{ATP}}$ channel is of importance for the $\mathrm{GH}$-induced regulation of vascular tone.

\section{Acknowledgements}

The authors would like to thank the Swegene Center for Bio-Imaging, Göteborg University and the Swegene Microarray Resource Center, Lund, Sweden for technical support. 


\section{Funding}

This work was supported by the Göteborg Medical Society, the Swedish Heart and Lung Foundation and the Swedish Research Council. There is no conflict of interest that would prejudice the impartiality of this work.

\section{References}

Baily RG, Lehman JC, Gubin SS \& Musch TI 1993 Non-invasive assessment of ventricular damage in rats with myocardial infarction. Cardiovascular Research 27 851-855.

Barreto-Filho JA, Alcantara MR, Salvatori R, Barreto MA, Sousa AC, Bastos V, Souza AH, Pereira RM, Clayton PE, Gill MS et al. 2002 Familial isolated growth hormone deficiency is associated with increased systolic blood pressure, central obesity, and dyslipidemia. Journal of Clinical Endocrinology and Metabolism 87 2018-2023.

Boger RH, Skamira C, Bode-Boger SM, Brabant G, von zur Muhlen A \& Frolich JC 1996 Nitric oxide may mediate the hemodynamic effects of recombinant growth hormone in patients with acquired growth hormone deficiency. A double-blind, placebo-controlled study. Journal of Clinical Investigation 98 2706-2713.

Capaldo B, Guardasole V, Pardo F, Matarazzo M, Di Rella F, Numis F, Merola B, Longobardi S \& Sacca L 2001 Abnormal vascular reactivity in growth hormone deficiency. Circulation 103 520-524.

Castillo C, Cruzado M, Ariznavarreta C, Gil-Loyzaga P, Lahera V, Cachofeiro V \& Tresguerres JA 2003 Body composition and vascular effects of growth hormone administration in old female rats. Experimental Gerontology 38 971-979.

Christensen KL, Mulvany MJ \& Jespersen LT 1990 Can mean arterial pressure be estimated from measurements of systolic and diastolic blood pressure, and vice versa? Journal of Hypertension 8 321-326.

Cittadini A, Stromer H, Katz SE, Clark R, Moses AC, Morgan JP \& Douglas PS 1996 Differential cardiac effects of growth hormone and insulin-like growth factor-I in the rat. A combined in vivo and in vitro evaluation. Circulation 93 800-809.

Clemow DB, Steers WD \& Tuttle JB 2000 Stretch-activated signaling of nerve growth factor secretion in bladder and vascular smooth muscle cells from hypertensive and hyperactive rats. Journal of Cellular Physiology 183 289-300.

Cybulsky MI, Iiyama K, Li H, Zhu S, Chen M, Iiyama M, Davis V, Gutierrez-Ramos JC, Connelly PW \& Milstone DS 2001 A major role for VCAM-1, but not ICAM-1, in early atherosclerosis. Journal of Clinical Investigation 107 1255-1262.

Emanueli C, Salis MB, Pinna A, Graiani G, Manni L \& Madeddu P 2002 Nerve growth factor promotes angiogenesis and arteriogenesis in ischemic hindlimbs. Circulation 106 2257-2262.

Evans LM, Davies JS, Anderson RA, Ellis GR, Jackson SK, Lewis MJ, Frenneaux MP, Rees A \& Scanlon MF 2000 The effect of GH replacement therapy on endothelial function and oxidative stress in adult growth hormone deficiency. European Journal of Endocrinology 142 254-262.

Fazio S, Cittadini A, Sabatini D, Merola B, Colao A, Biondi B, Longobardi S, Lombardi G \& Sacca L 1997 Growth hormone and heart performance. A novel mechanism of cardiac wall stress regulation in humans. European Heart Journal 18 340-347.

Fujii K, Onaka U, Goto K, Abe I \& Fujishima M 1999 Impaired isoproterenol-induced hyperpolarization in isolated mesenteric arteries of aged rats. Hypertension 34 222-228.

Fujita A \& Kurachi Y 2000 Molecular aspects of ATP-sensitive K+ channels in the cardiovascular system and $\mathrm{K}+$ channel openers. Pharmacology and Therapentics 85 39-53.

Goffin V, Shiverick KT, Kelly PA \& Martial JA 1996

Sequence-function relationships within the expanding family of prolactin, growth hormone, placental lactogen, and related proteins in mammals. Endocrine Reviews 17 385-410.
Hasdai D, Rizza RA, Holmes DR Jr, Richardson DM, Cohen P \& Lerman A 1998 Insulin and insulin-like growth factor-I cause coronary vasorelaxation in vitro. Hypertension 32 228-234.

He NG, Awasthi S, Singhal SS, Trent MB \& Boor PJ 1998 The role of glutathione $\mathrm{S}$-transferases as a defence against reactive electrophiles in the blood vessel wall. Toxicology and Applied Pharmacology 152 83-89.

Isgaard J, Bergh CH, Caidahl K, Lomsky M, Hjalmarson A \& Bengtsson BA 1998 A placebo-controlled study of growth hormone in patients with congestive heart failure. European Heart Journal 19 1704-1711.

Kunsch C \& Medford RM 1999 Oxidative stress as a regulator of gene expression in the vasculature. Circulation Research 85 753-766.

Longobardi S, Cittadini A, Stromer H, Katz SE, Grossman JD, Clark RG, Morgan JP \& Douglas PS 2000 Echocardiographic assessment of cardiac morphology and function in mutant dwarf rats. Growth Hormone and IGF Research 10 242-247.

Miki T, Suzuki M, Shibasaki T, Uemura H, Sato T, Yamaguchi K, Koseki H, Iwanaga T, Nakaya H \& Seino S 2002 Mouse model of Prinzmetal angina by disruption of the inward rectifier Kir6 1 . Nature Medicine 8 466-472.

Mills DE \& Woods RB 1985 Interaction of prolactin with adrenal hormones in blood pressure regulation in rats. American Journal of Physiology 249 E614-E618.

Pfeifer M, Verhovec R, Zizek B, Prezelj J, Poredos P \& Clayton RN 1999 Growth hormone $(\mathrm{GH})$ treatment reverses early atherosclerotic changes in GH-deficient adults. Journal of Clinical Endocrinology and Metabolism 84 453-457.

Ringqvist A, Caidahl K, Petersson AS \& Wennmalm A 2000 Diurnal variation of flow-mediated vasodilation in healthy premenopausal women. American Journal of Physiology Heart and Circulatory Physiology 279 H2720-H2725.

Rosen T \& Bengtsson BA 1990 Premature mortality due to cardiovascular disease in hypopituitarism. Lancet 336 285-288.

Rossoni G, Locatelli V, De Gennaro Colonna V, Torsello A, Schweiger F, Boghen M, Nilsson M, Bernareggi M, Muller EE \& Berti F 1999 Growth hormone and hexarelin prevent endothelial vasodilator dysfunction in aortic rings of the hypophysectomized rat. Journal of Cardiovascular Pharmacology 34 454-460.

Safar ME, Levy BI \& Struijker-Boudier H 2003 Current perspectives on arterial stiffness and pulse pressure in hypertension and cardiovascular diseases. Circulation 107 2864-2869.

Scarisbrick IA, Jones EG \& Isackson PJ 1993 Coexpression of mRNAs for NGF, BDNF, and NT-3 in the cardiovascular system of the pre- and postnatal rat. Journal of Neuroscience 13 875-893.

Smith JC, Evans LM, Wilkinson I, Goodfellow J, Cockcroft JR, Scanlon MF \& Davies JS 2002 Effects of GH replacement on endothelial function and large-artery stiffness in GH-deficient adults: a randomized, double-blind, placebo-controlled study. Clinical Endocrinology 56 493-501.

Ting AY \& Endy D 2002 Signal transduction. Decoding NF-kappaB signaling. Science 298 1189-1190.

Tivesten A, Caidahl K, Kujacic V, Sun XY, Hedner T, Bengtsson BA \& Isgaard J 2001 Similar cardiovascular effects of growth hormone and insulin-like growth factor-I in rats after experimental myocardial infarction. Growth Hormone and IGF Research 11 187-195.

Tivesten A, Bollano E, Andersson I, Fitzgerald S, Caidahl K, Sjogren K, Skott O, Liu JL, Mobini R, Isaksson OG et al. 2002 Liver-derived insulin-like growth factor-I is involved in the regulation of blood pressure in mice. Endocrinology 143 4235-4242.

Zettler C, Head RJ \& Rush RA 1991 Chronic nerve growth factor treatment of normotensive rats. Brain Research 538 251-262.

Received 25 February 2004

Accepted 18 June 2004 